\title{
Ethnobotanical researches in Qobustan district (Azerbaijan) and development of electronic database of useful plants
}

\author{
Naiba P. Mehdiyeva ${ }^{1}$ \\ Institute of Botany, Azerbaijan National Academy of Sciences, \\ Badamdar 40, Baku, AZ1004, Azerbaijan \\ Laman F. Hamidova \\ Institute of Information Technology, Azerbaijan National \\ Academy of Sciences, B. Vahabzade 9A, Baku, AZ1141, \\ Azerbaijan
}

\begin{abstract}
The article presents the results of ethnobotanical studies conducted in Qobustan district of Azerbaijan and the creation of an electronic database of useful plants of the district. The situation in ethnobotany is briefly analyzed, the necessity and advantages of the use of modern information and communication technologies in this field are substantiated. It was determined that of the 1200 plant species distributed in Qobustan, 443 species belonging to 293 genera and 82 families are useful. Most of them are medicinal (428 species), ornamental (214) and food (179), significantly less fodder (68), technical (62), dye (59) and melliferous plants (58). The local population most often use 89 species belonging to 72 genera and 35 families. The data on these species, indicating their useful properties are given. The main characteristics of the electronic database, its structure, working principle, information on 24 parameters of plants entered into the database and interface of output information about plants are provided.
\end{abstract}

Key Words: medicinal, food, fodder, dye plants, information technologies

\section{INTRODUCTION}

In the context of the rapid growth of the world's population and gradually expansion of consumption processes since the second half of the XX century, the necessity of the identification of new sources of raw materials for the discovery and acquisition of material products, including food and medicinal, as well as other economically important useful products for human activity has become actual scientific-practical problem at the present time. One of the ways for the solution of this problem in modern times, nowadays making more effective use of the experience of the past, clarifying,

Accepted for publication: 15 April 2020

'E-mail: naiba_m@mail.ru evaluating the range and useful properties of historically used plant species returning the forgotten species to the reuse cycle are one of the important issues.

As a result of scientific-technical and technological progress and the modernization lifestyle, traditional forms in nutrition and medicine had been left aside. For this reason, information about the use of plants, collected over the centuries and passed down through the generations, is being forgotten and in danger of being lost. It should be noted that plants are widely used not only for physical needs, but also for spiritual needs by performing various rituals and ceremonies. Therefore, the study of traditions in this area serves to the preservation of the material-spiritual and cultural heritage of the people as a whole.

There was a practical approach to the study of plants in the medieval Muslim East, and botany developed as a science of medicinal plants [Abu Ali Ibn Sina, 1956]. Starting around the middle of the 19th century, the use of plants by humans within the botanical science was formed as a separate direction which was called as ethnobotany later [Harshberger, 1896]. Interest in ethnobotany has grown significantly in the last quarter of the XX century. Studies show that the number of documents in the field of ethnobotany increased twofold in the 1990s compared to the 1980s [Simmonds, 2009]. Thus, over the last years in certain regions of Iran and Turkey, a number of ethnobotanical studies were carried out to study the practice of applying plants in various fields of daily life [Özgökçe, Özçelik, 2004; Sargin, Büyükcengiz, 2019; Tahereh Maleki, Hossein Akhani, 2018]. In Turkey, work is under way to collect and accumulate ethnobotanical information in Excel format throughout the country and it is planned that a single electronic database will be created on the basis of it in the future [https://www. researchgate.net/project/].

In general, sufficient activity has been observed in scientific activities conducted in Azerbaijan in the field of ethnobotany in recent years. During this period, large scientific studies were carried out and numerous works were published on the useful plants used in folk medicine, cuisine and cookery, carpet weaving and dyeing in Azerbaijan [Alekperov, 1999; Alekperov, 2001; Alizade et al., 2019; Gasimov, 1998; Gasimov, 2004; Gasimov, 2009; Gasimov, 2010; Gasimov, 2018; 
Haj1 Suleyman, 2017; Mehdiyeva, 2014; Nuskhecat, 2005].

At the same time, it should be noted that the opportunities of modern information and communication technologies are not properly used in ethnobotanical research, collection, processing and analysis of information on plants, their useful properties and use, low priority was given to the creation of electronic databases. As a minority exception, it can be noted that the database on medicinal plants of Azerbaijan contains information on 26 parameters about 1547 plant species belonging to 178 families and 740 genera. This database is an important scientific source for the study of the plant diversity, distribution, useful properties, use of plants and their management and especially protection [Mehdiyeva, 2015].

Modern information and communication technologies create great opportunities for collecting and linking ethnobotanical data obtained in Azerbaijan, eliminating information gaps, addressing human needs and preserving them for future generations, and in this regard, their application in scientific research is one of the important issues.

Our research is aimed to studying the plants used by the population in Qobustan district for various purposes, determining and studying their useful properties, as well as creating a database based on information about them.

\section{MATERIAL AND METHODS}

Studies were carried out in 2018-2019 in Qobustan district located in the eastern part of the Republic of Azerbaijan (Fig. 1). Field studies were carried out by the route method, within the altitude of 764-979 m above sea level in the vicinity 11 villages (Nabur, Bakla, Takla, Chukhanli, Arabshalbash, Takla-Mirzababa, Sundu, Jayirli, Chalov, Poladli, Khilmilli), in of which the vegetation cover is more diverse.

A questionnaire was developed to collect information. The survey was conducted among people over 50 years of age, including healers, teachers, shepherds, housewives, etc. During the interviews, information was obtained on the local name, location and growing conditions, used parts of plants, time of the collection of raw materials, and the use for healing, food and other purposes, methods of preparing healing products (decoction, infusion, ointments) and various dishes. To determine the collected species, "Flora of Azerbaijan" [1950-1961], as well as the herbarium of the Herbarium Foundation of the Institute of Botany of the ANAS (BAK) were used. The nomenclature is in accordance

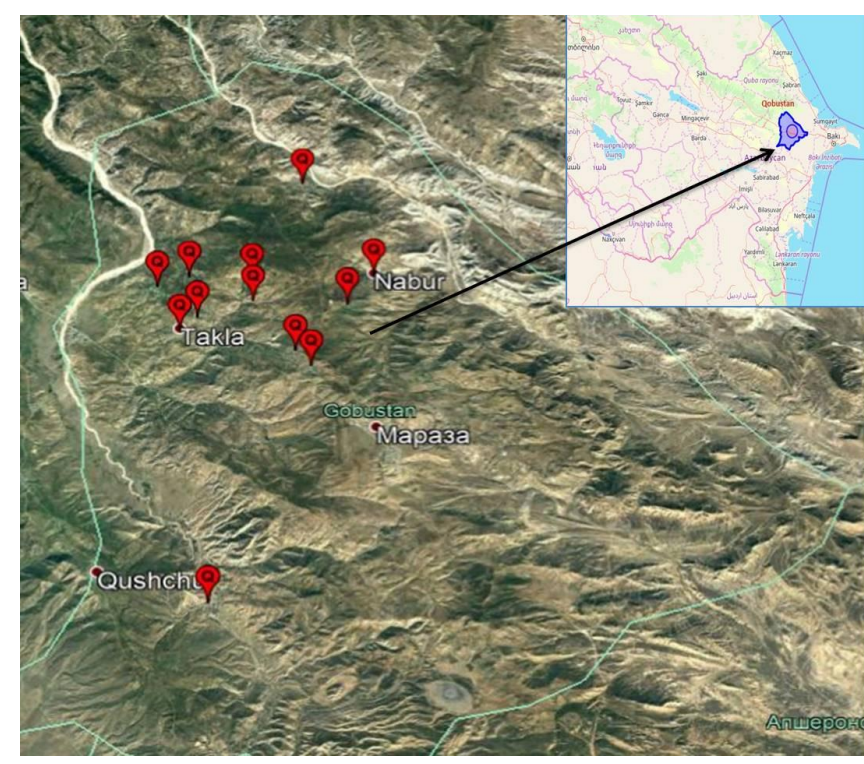

Figure 1. The map of routes of investigated areas.

with World Flora Online.

An ethnobotanical database is a collection of ethnobotanical data. SQL server and MS Access were used as databases in the development of ethnobotanical information system. This database consists of structured linked tables. Addition of new information, deletion, change or update of the existing data are possible by using various algorithms and queries. The main requirement in the proposed database is the development of structured tables. Here, various parameters have been identified to determine the useful properties of plants, and the ethnobotanical database has been prepared in accordance with these parameters.

The database present 24 ethnobotanical parameters of 100 plants with features existing in Azerbaijan: to which family the plants belongs, their scientific name, names in Azerbaijani, English and Russian, as well as names given by the local population in different territories, botanical description (life form of plant, shape of flower, structure of fruit, time of blooming and fruiting, height of plant, poisonousness), distribution areas (natural economic zones, economic and administrative districts), chemical composition, fields of use (traditional medicine, food, pharmacology, cosmetics industries, ornomental, etc.), use in the treatment of diseases, used parts and forms of use (brewing, extract, infusion, etc.), photos and other data. In the form of a diagram, the relationship of these tables is shown and the architectural structure of the ethnobotanical information system is proposed. Statistical analysis was carried out using PAST 3.15 [Hammer et al., 2001] and Microsoft Excel. 
Qobustan district is located in the eastern and southeastern foothills of the Greater Caucasus Mountain and its relief is formed on the basis of rocks, valleys and ravines. Average height of 600-700 m., at the sloping to the south-east. The territory of Qobustan consists of mountain plateaus, hilly foothills and plains.

The soil cover of Qobustan is composed of graybrown, light chestnut soils. The climate of the region is mainly semidesert. The vegetation types here are semidesert, mountain-xerophyte and mountainmeadow. Of the approximately 5000 plant species distributed in the flora of Azerbaijan [Asgerov, 2011], about 1200 are found here [Musaev, Fataliev, 2004]. Most of them are higher flowering plants. Saltwort (Salsola dendroides Pall., S. nodulosa (Moq. Iljin), sagebrush (Artemisia alpina Pall. ex Willd., A. fragrans Willd.), ephemeral plant (Calendula arvensis (Vaill.) L., Senecio leucanthemifolius subsp. vernalis (DC.) Greuter, Spergularia diandra (Guss.) Heldr.) and other plant species are found in the relatively saline areas of Qobustan.

\section{RESULTS AND DISCUSSION}

The analysis of literary sources [Flora of Azerbaijan, 1950-1961; Atamov, 1981] and the results of our studies revealed that out of the total number of species (1200) distributed in Qobustan [Musayev, Fataliyev, 2004], the floristic composition of useful plants in this district include 443 species belonging to 293 genera and 82 families. Most of them $-96.6 \%$ (428 species) account for medicinal plants, of which 5\% (22 species) are officinal. A significant number of species are ornamental (214) and food (179) plants, which account for $48.3 \%$ and $40.1 \%$, respectively. The smallest number of species belongs to fodder (68), technical (62), dyeing (59) and melliferous (58) plants, which account for 13.1 to $15.3 \%$.

An analysis of the systematic structure of useful plants of Qobustan revealed that the predominant number of families, genera and species belongs to the division Magnoliophyta (73, 287 and 428, respectively), the smallest are Bryophyta $(1,1,1)$, Gnetophyta (1, 1, 2), Pinophyta $(1,1,3)$, Equisetophyta $(1,1,4)$, Polypodiophyta $(4,5,6)$. The class Magnoliopsida is represented by 62 families, 241 genera and 358 species, Liliopsida - 12, 43 and 69 respectively.

The greatest species richness in the class Magnoliopsida is possessed by the families Amaranthaceae Juss., Apiaceae Lindl., Asteraceae Giseke, Boraginaceae Juss., Brassicaceae Burnett,
Caryophyllaceae Juss., Fabaceae Lindl., Lamiaceae Lindl., Ranunculaceae Juss., Rosaceae Juss., comprising of 7-29 genera (52.56\%) and 15-40 species $(54.63 \%)$, these families account for $12.20 \%$. In the class Liliopsida, the most distinguished families are Amaryllidaceae J.St.-Hil., Asparagaceae Juss., Cyperaceae Juss., Liliaceae Juss., Orchidaceae Juss., Poaceae Barnhart, comprising of 2 to 15 genera $(11.94 \%)$ and 4 to 19 species (12.64\%), which account for $7.32 \%$. Most families (53) include one-two genera and one-two species. The distribution of useful plant species by application forms in the leading families is shown in figure 2.

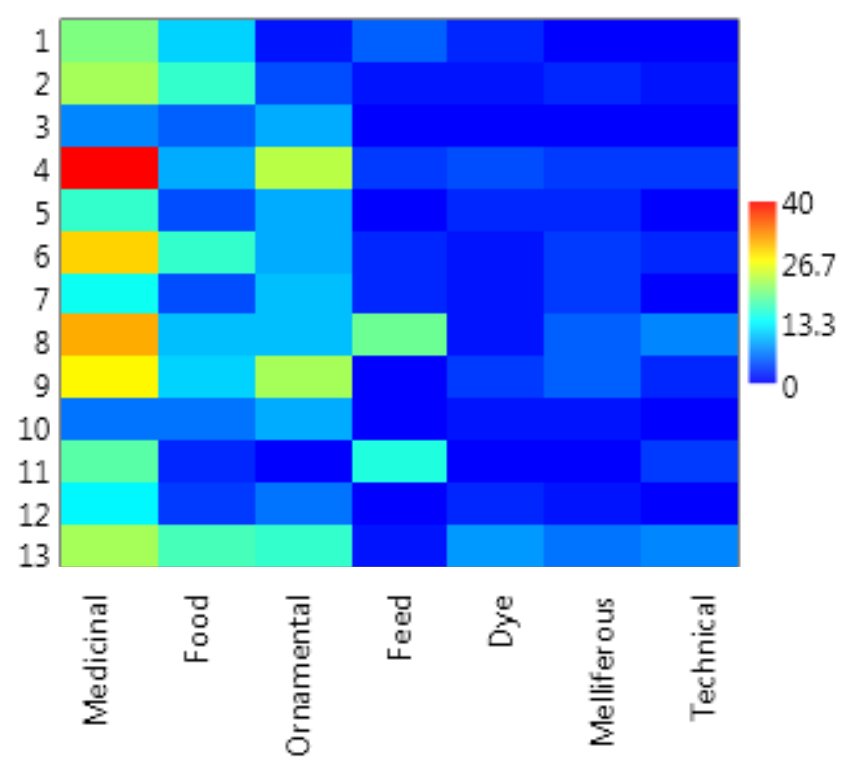

Figure 2. Distribution of useful plant species in leading families.

On the ordinate axis of the family: 1. Amaranthaceae Juss., 2. Apiaceae Lindl., 3. Asparagaceae Juss., 4. Asteraceae Giseke, 5. Boraginaceae Juss., 6. Brassicaceae Burnett, 7. Caryophyllaceae Juss., 8. Fabaceae Lindl., 9. Lamiaceae Lindl., 10. Orchidaceae Juss., 11. Poaceae Barnhart, 12. Ranunculaceae Juss., 13. Rosaceae Juss. The scale indicates the number of species.

As can be seen from figure 2, the largest number of plant species with medicinal properties is presented in the family Asteraceae (40 species - 9.03\%), food Apiaceae and Brassicaceae (on 16 - 3.61\%), fodder - Fabaceae and Poaceae (19 - 4.29\%, 15 - 3.39\% respectively), ornamental - Asteraceae and Lamiaceae (23 - 5.19\%, $22-4.5 \%$ respectively), dyeing - Rosaceae (8 - 1.81\%), melliferous - Fabaceae, Lamiaceae (on 5 
species - 1.13\%) and Rosaceae (6 - 1.35\%), technical Fabaceae and Rosaceae (each 7 species $-1.58 \%$ ).

The greatest number of species is distinguished by the genera Salvia L. (7 species), Chenopodium L., Euphorbia L., Ranunculus L. (each 6 species), Allium L., Lepidium L., Medicago L. (each 5 species), Erysimum L., Carex L., Trifolium L., Galium L. (each 4 species), Cirsium Hill, Equisetum L., Euphrasia L., Heliotropium L., Juncus L., Juniperus L., Malva L., Plantago L., Rosa L., Securigera DC., Sisymbrium L., Teucrium L., Tulipa L., Veronica L. (each 3 species). The remaining 195 genera represented by $1-2$ species account for $66.55 \%$.

Among the useful plants of Qobustan, 9 species are endemic to the Caucasus (Salsola nodulosa, Cladochaeta candidissima (M.Bieb.) DC., Stizolophus coronopidolius (Lam.) Cass., Gypsophila capitata M. Bieb., Juniperus communis var. saxatilis Pall., Quercus iberica Steven ex M. Bieb., Salvia karabachensis Pobed., S. verbascifolia M. Bieb., Scutellaria orientalis L. and Anacyclus ciliatus Trautv. which is endemic of Azerbaijan.

The survey showed that the local population most often used 89 species belonging to 72 genera and 35 families. Many of them are both medicinal, food, fodder, dyeing, melliferous, ornamental and used in a variety of areas and in various forms.

For example, 87 species out of a total of 89 are used mainly as a therapeutic agent: in the form of infusions and decoctions for diseases of the gastrointestinal tract, liver, as a laxative, choleretic, and also for colds, as diaphoretic and expectorant; in the form of ointments for skin diseases, tumors and as a wound healing in purulent wounds and ulcers. At the same time, the most popular among the population as medicinal are as follows: Salicornia europea L., Spinacia tetrandra Steven ex M. Bieb., Eryngium campestre L., Falcaria vulgaris Bernh., Carthamus lanatus L., Achillea filipendulina Lam., Echinops sphaerocephalus L., Helichrysum rubicundum (C. Koch) Bornm., Xeranthemum inapertum (L.) Mill., Anchusa azurea Mill., Symphytum caucasicum M. Bieb., Alliaria petiolata (M. Bieb.) Cavara et Grande, Lepidium campestre (L.) R.Br., Celtis australis subsp. caucasica (Willd.) C.C. Towns, Elaeagnus rhamnoides (L.) A.Nelson, Hypericum perforatum L., Juncus articulatus L., Mentha longifolia (L.) L., Origanum vulgare L., Salvia verticillata L., Plantago major L., Primula veris subsp. macrocalyx (Bunge) Lüdi, Consolida orientalis (J. Gay) Schröding, Crataegus kyrtostyla Fingerh., Filipendula vulgaris Moench, Rosa canina L., Viola arvensis Murray etc.

Also, 70 species are in demand as food. Leaves and young shoots of Atriplex tatarica L., Chenopodium album L., Bifora radians M. Bieb., Chaerophyllum bulbosum L., Pimpinella aromatica M. Bieb., P. peregrina L., Silybum marianum (L.) Gaertn., Capsella bursa-pastoris (L.) Medik., Lepidium draba L., Sinapis arvensis L., Capparis spinosa L., Stellaria media (L.) Vill., Ziziphora capitata L., Malva sylvestris L., M. neglecta Wallr., Ficus carica L., Morus nigra L., Polygonum aviculare L., Rumex crispus L., Nigella arvensis L., Fragaria vesca L., Mespilus germanica L., Vitis vinifera L., Eremurus spectabilis M. Bieb. and others are used in food as raw and for the preparation of various dishes (soups, dovga, pilaf, gutab, pies, etc.), drinks, teas, marinades. The above ground parts and seeds of some of these plants are considered to be a good spice.

Species of Avena sativa L., Chenopodium vulvaria L., Elymus repens (L.) Gould, Juncus bufonius L., J. gerardii Loisel., Koeleria macrantha (Ledeb.) Schult, Lathyrus pratensis L., Salicornia europaea L., Trifolium arvense L., T. pratense L., Stellaria holostea L., etc. all about are used as fodder plants in the composition of hay and silage for livestock and poultry.

About 30 species of plants are used for dyeing wool yarn in yellow, red, brown, and other colors (Anchusa azurea Mill., Berberis iberica Steven et Fischer ex DC., Carthamus lanatus, C. oxycantha, Cirsium arvense (L.) Scop., Crataegus orientalis Pall. ex M.Bieb., Falcaria vulgaris Bernh., Juniperus communis var. saxatilis Pall., Punica granatum L., Rosa canina L., Symphytum caucasicum M.Bieb., etc.).

For technical purposes (making mats, broom, baskets, etc.), 21 species are in use by (Carex riparia Curtis, Celtis australis subsp. cancasica, Elaeagnus rhamnoides, Limonium meyeri (Boiss.) Kuntse, Mespilus germanica, Punica granatum, Xeranthemum cylindraceum Sm., etc.).

It was also established that 42 species are ornamental and 27 melliferous plants. The collection of plants by the local population is carried out from early spring to late autumn.

Application of MS Access in the development of ethnobotany database.

As an example, the information on the useful properties of sea buckthorn in MS Access is described as follows (Fig. 3, 4). The botanical characteristics and useful properties of sea-buckthorn (Elaeagnus rhamnoides 


\section{Botanical characteristics of plants}

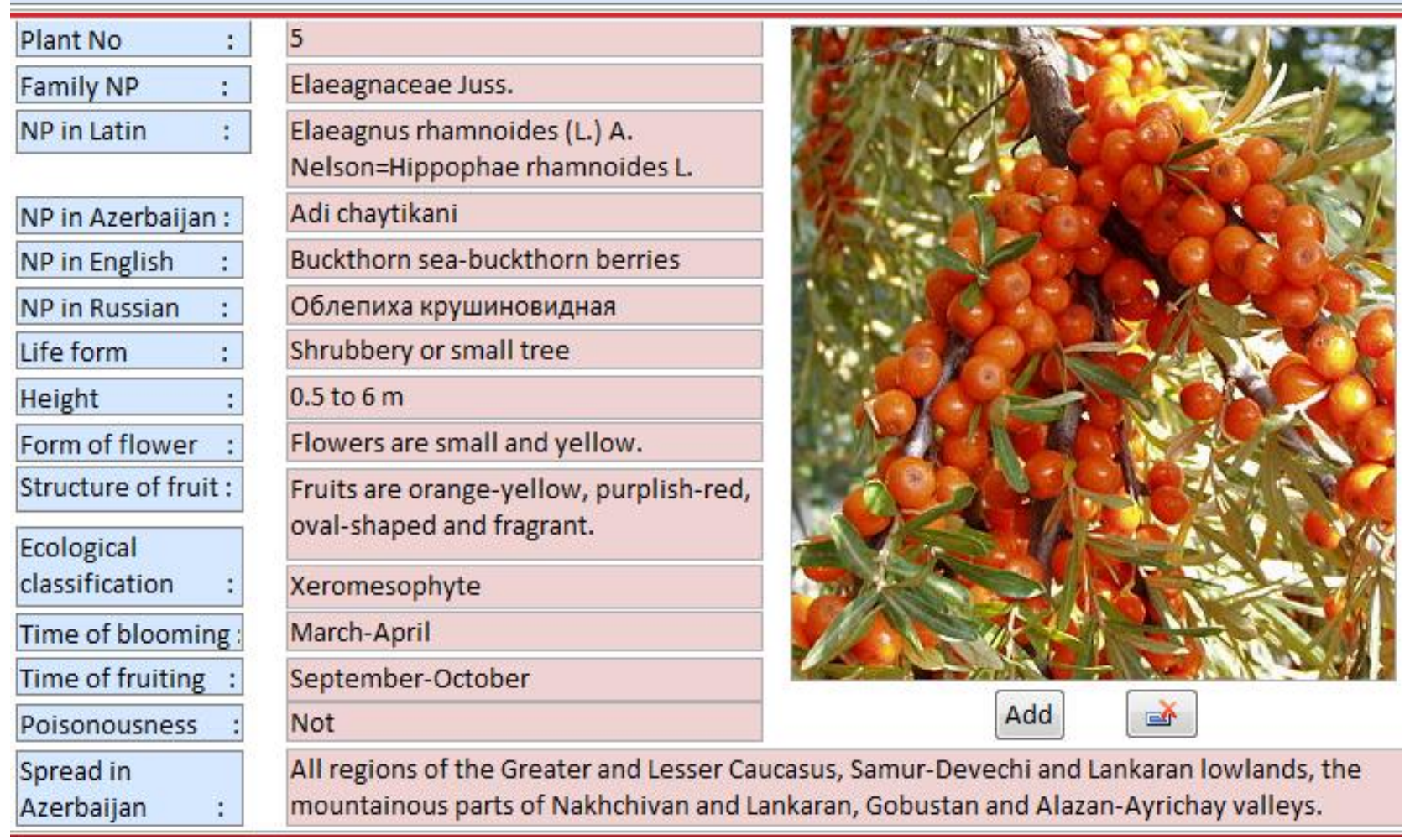

Figure 3. A description of the botanical characteristics of sea-buckthorn in MS Access.

\section{Effect and use of plants}

\begin{tabular}{|c|c|c|}
\hline Chemical composition & $:$ & $\begin{array}{l}\text { B1, B2, B12, C, E, K, PP, phytosterols, malic acid, polyphenols, carotenoids, } \\
\text { fatty oil, flavonoids, alkaloids, fructose and glucose }\end{array}$ \\
\hline Use fields & $:$ & $\begin{array}{l}\text { Traditional medicine, food, farmacology, cosmetics industries, forage for } \\
\text { polutry }\end{array}$ \\
\hline $\begin{array}{l}\text { Use in the treatment of } \\
\text { diseases }\end{array}$ & : & $\begin{array}{l}\text { Ulcers of stomach and duodenum, diseases of skin, eye, avitaminosis, } \\
\text { rheumatism, cancer, veterinary medicine }\end{array}$ \\
\hline Side effects & $:$ & $\begin{array}{l}\text { Patients who suffer from acute cholesterol, hepatitis, pancreatitis, } \\
\text { gastritis,colitis, and gallbladder stones may harm if intake intravenous sea- } \\
\text { buckthorn oil. }\end{array}$ \\
\hline Used plant parts & : & Leaves, young branches and berries \\
\hline Using plant forms & : & Infusion, juice, syrup, oil, alcoholic tincture \\
\hline Reference & : & $\begin{array}{l}\text { Valida M. Alizade, Naiba P. Mehdiyeva, Vugar N. Karimov, Aida Q. Ibrahimova } \\
\text { "Plants of the Greater Caucasus (Azerbaijan)", Baku, } 2019 .\end{array}$ \\
\hline Add & & \\
\hline
\end{tabular}

Figure 4. A description of effect, use and chemical composition of sea-buckthorn in MS Access. 
(L.) A.Nelson = Hippophae rhamnoides L.) has been represented in MS Access and shown below.

\section{CONCLUSIONS}

In recent years, throughout the world, including in Azerbaijan, there is an increased interest in ethnobotanical research, as well as in one of the areas of expansion of the nomenclature of useful plants and search for new sources of plants. Active work is implemented on the accumulation, restoration of lost and forgotten information about useful plants, traditions of their use [Alekperov, 1998; Ethnobotany of the Caucasus, 2017]. Research on the scientific basis of folk experience in the use of plants, especially in medical purposes is significantly expanded. The opportunities of modern information and communication technologies are successfully used in this case. Ethnobotanical studies in the Qobustan district, which showed that almost 76.5\% of the useful plants of Qobustan have a comprehensive application, and the electronic database developed on the basis of the results of this study of useful plants of the district, represent a certain contribution to the expansion of the nomenclature of useful plants and search for new sources of plant resources in Azerbaijan.

\section{REFERENCES}

Abu Ali ibn Sina (Avicenna) (1956) Canon of medical science, Book 2. About simple medicines. Tashkent: Publishing House of the Academy of Sciences of Uzbekistan. SSR, 828 s. [Абу Али ибн Сина (Авиценна) (1956) Канон врачебной науки. Кн.2. О простых лекарствах. - Ташкент: Изд-во АН Узб. CCP, 828 с.]

Alekperov F.U. (1998) Written sources of the X-XVIII centuries on the protection of health in medieval Azerbaijan: Abstract. dis. Doc. Histor. Scie. Baku, 39 p. [Алекперов Ф.У. (1998) Письменные источники X-XVIII вв. об охране здоровья в средневековом Азербайджане: Автореф. дис. докт. истор. наук. Баку, 39 с.]

Alekperov F.U. (1999) Health protection in medieval (X-XVIII centuries) in Azerbaijan, Baku: Irshad, 88 p. (In Russian) [Алекперов Ф.У. (1999) Охрана здоровья в средневековом (X-XVIII вв.) Азербайджане, Баку: Иршад, 88 с.]

Alekperov F.U. (2001) A Thousand and One Secret of the East Baku: "T" Publishing and Printing Centre, 494 р. [Алекперов Ф.У. (2001) Тысяча и один секрет Востока. Баку: «Т» Издательско- полиграфический центр, 494 с.]

Alizade V., Mehdiyeva N., Karimov V., Ibrahimova A. (2019) Greater Caucasus (Azerbaijan) (editor Thomas Borsch), Baku: "Red N Line" Publishing House, $352 \mathrm{p}$.

Asgerov A.M. (2011) Abstract of the flora of Azerbaijan. Additions and changes (1961-2009), Baku: Elm, 202 p. [Osgərov A.M. (2011) Azərbaycan florasının konspekti. Olavələr və dəyişikliklərlə (1961-2009), Bak1: Elm, 202 s.]

Copy (Secrets of Ancient Medicine) (2005) Translation and compilation by the scientific worker of the Institute of Manuscripts of ANAS Z. Mammadova. Baku: Masterprint Publishing House, 35 p. [Nüsxəcat (Qədim təbabətin sirləri). Tərcümə və tərtib AMEA Olyazmalar İnstitutunun elmi işçisi Z. Məmmədova. Bak1: "Masterprint" nəşriyyatı, 35 s.]

Ethnobotanical Database of Turkey [https://www. researchgate.net/project]

Ethnobotany of the Caucasus (2017) Mehdiyeva N.P., Alizade V.M., Guliyev I.S., Alirzayeva E.H. (editors Rainer W.Bussman). William L.Brown Center, Missouri Botanical Garden. Springer reference, 746 p.

Flora of Azerbaijan (1950-1961) Baku: Publishing House of the Academy of Sciences of the Azerbaijan SSR. [Флора Азербайджана (1950-1961) Баку: Издательство Академии Наук Азербайджанской CCP.]

Gasimov M.A. (1998) Dye plants of Azerbaijan and the possibilities of their use. Abstract dis. Doc. of Biol. Sci. Baku, 44 p. [Касумов М.А. (1998) Красильные растения Азербайджана и возможности их использования. Автореф. дис. докт. биол. наук. Баку, 44 с.]

Gasimov M.A., Gadirova G.S. (2004) Encyclopedia of spices and wild vegetables. Baku: Elm, 303 p. [Qasımov M.A., Qədirova G.S. (2004) Odviyyat və yabanı tərəvəz bitkilərinin ensiklopediyası. Bakı: Elm, 303 s.]

Gasimov Q.Z., Guliev V.B., Ibadullayeva S.D. (2009) Wild food plants in the Nakhchivan Autonomous Republic of Azerbaijan based on ethnobotanical studies. Plant Resources, 45(2): 110-116. [Гасымов Q.Z., Гулиев В.Б., Ибадуллаева С.Д. (2009) Дикорастущие пищевые растения в Нахичеванской автономной республике Азербайджана по материалам этноботанических исследований. Растительные ресурсы, 45(2): 
110-116.]

Gasimov M.A., Khalilov V.S., Gasimova T.A. (2010) Wild vegetable plants of Azerbaijan and perspectives of their use. Proceedings of Society of Azerbaijan Botanists, 1: 371-396. [Qasımov M.Ә., Xəlilov V.S., Qasımova T.A. (2010) Azərbaycanın yabanı tərəvəz bitkiləri və onların istifadə olunma perspektivləri. Azarbaycan Botaniklar Camiyyatinin Elmi asarlari, 1: 371-396.]

Gasimov H.Z., Ibadullayeva S.J., Seyidov M.M., Shiraliyeva G.Sh. (2018) Wild vegetable plants of the flora of the Nakhchivan Autonomous Republic. Nakhchivan: "Ajami" Publishing and Printing Union, 416 p. [Qasımov H.Z., İbadullayeva S.C., Seyidov M.M., Şirəliyeva G.Ş. (2018) Naxçıvan Muxtar Respublikası florasının yabanı tərəvəz bitkiləri. Naxçıvan: “Әcəmi” Nəşriyyat -Poliqrafiya Birliyi, 416 s.]

Haji Suleyman Gajar Iravani (2017) Wisdom Treasure (Fawaidul-Hikmat) Baku: "Europe" publishing house, 270 p. [Hac1 Süleyman Qacar İrəvani (2017) Hikmət xəzinəsi (fəvaidul-Hikmət) Bak1: "Avropa" nəşriyyat1, $270 \mathrm{~s}$.]

Hammer Ø., Harper D.A.T., Ryan P.D. (2001) PAST: Paleontological statistics software package for education and data analysis. Palaeontologia Electronica, 4(1): 9 p.

Harshberger J.W. (1896) The purposes of ethnobotany. Botanical gazette, 21: 146-154.

Hatamov V.V. (1981) Analysis of the flora of some steppe phytocenoses of Qobustan. In the book: Materials of the republican scientific conference of graduate students. - Baku, II book: 6-9. [Атамов В.В. (1981) Анализ флоры некоторых степных фитоценозов Кобустана. В кн.: Материалы республиканской научной конференции аспирантов. - Баку, II кн.: 6-9]

Mehdiyeva N.P. (2014) About some plants of the flora of Azerbaijan used in traditional medicine and cooking. Traditional medicine, 4(39): 25-32. [Мехтиева Н.П. (2014) О некоторых растениях флоры Азербайджана, используемых в народной медицине и кулинарии. Традищионная медищина, 4(39): 25-32]

Mehdiyeva N.P. (2015) Biodiversity of medicinal plants of flora of Azerbaijan. Abstract. dis. Doc. of Biol. Sci. Baku, 44 p. [Мехтиева Н.П. (2015) Биоразнообразие лекарственных растений флоры Азербайджана. Автореф. дис. докт. биол. наук. Баку, 44 с.]

Musayev S.Q., Fataliyev R.A. (2004) Flora of Azerbaijan: New Data. Proceedings of the Institute of Botany of the NAS of Azerbaijan, XXV: 1622. [Мусаев С.Г., Фаталиев Р.А. (2004) Флора Азербайджана: Новые данные. Труды Института ботаники НАН Азербайджана, XXV: 16-22]

Özgökçe F., Özçelik H. (2004) Ethnobotanical aspects of some taxa in east Anatolia, Turkey. Economic Botany, 697-704.

Sargin S.A., Büyükcengiz M. (2019) Plants used in ethnomedicinal practices in Gulnar district of Mersin, Turkey. J Herb Med, 15: 100224.

Simmonds M.S.J. (2009) Opportunities and Challenges for Ethnobotany at the Start of the Twenty-First Century. USA: Springer, 127-140.

Tahereh Maleki, Hossein Akhani (2018) Ethnobotanical and ethnomedicinal studies in Baluchi tribes: A case study in Mt. Taftan, southeastern Iran. Journal of Ethnopharmacology, 163-177.

World Flora Online [http://www.worldfloraonline.org/]

\section{Qobustan rayonunda (Azərbaycan) etnobotaniki tədqiqatlar və faydalı bitkilərinin elektron verilənlər bazasının yaradılması}

\section{Naibə P. Mehdiyeva}

AMEA Botanika Institutu, Badamdar şossesi 40, Bakl, AZ1004, Azarbaycan

\section{Ləman F. Həmidova}

AMEA Informasiya Texologiyaları Institutu, B.Vağabzadə küç, 9A, Bakı, AZ1141, Azarbaycan

Məqalədə Qobustan rayonunda aparılmış etnobotaniki tədqiqatların və regionun faydalı bitkilərinin elektron verilənlər bazasının yaradılması işinin nəticələri əks olunmuşdur. Q1sa şəkildə etnobotaniki vəziyyət təhlil edilmiş, bu sahədə müasir informasiya-kommunikasiya texnologiyalarının tətbiqinin zəruriliyi və üstünlükləri əsaslandırılmışdır. Müəyyən edilmişdir ki, Qobustanda yayılmış 1200 bitki növündən, 82 fəsiləyə və 293 cinsə aid 443 növü faydalı bitkidir. Onların çoxu dərman (428), dekorativ (214), qida (179), az sayda isə yem (68), texniki (62), boyaq (59) və balverən (58) bitkilərdir. Yerli əhali tərəfindən daha çox 35 fəsilə, 72 cinsə aid 89 növ istifadə edilir. Daha çox istifadə edilən növlər və onların faydalı xüsusiyyətləri barədə məlumatlar verilmişdir. Elektron məlumat bazasının xarakteristikası, onun strukturu, fəaliyyət prinsipi, bazaya daxil edilən bitkilər barədə 24 parametr üzrə çıxış məlumatlarının istifadəçi 
interfeysi öz əksini tapmışdır.

Açar sözlor: dorman, qida, yem, boyaq bitkilari, informasiya texnologiyalart

Этноботанические исследования в Гобустанском районе (Азербайджан) и создание электронной базы данных полезных растений региона

\section{Наиба П. Мехтиева}

Институт Ботаники НАНА, Бадамдарское шоссе 40, Баку, AZ1004, Азербайджан

\section{Ляман Ф. Гамидова}

Интитут Информационных Технологий НАНА, ул.Б.Вагабзаде, 9А, AZ1141, Азербайджан

В статье излагаются результаты этноботанических исследований, проведенных в Гобустанском районе Азербайджана и создание электронной базы данных полезных растений региона. Кратко проанализировано положение дел в этноботанике, обоснована необходимость и преимущества использования в этой области современных информационно-коммуникационных технологий. Установлено, что из 1200 видов растений, распространенных в Гобустане, 443 вида, относящихся к 293 родам и 82 семействам являются полезными. Больше всего среди них лекарственных (428 вида), декоративных (214) и пищевых (179), значительно меньше кормовых (68), технических (62), красильных (59) и медоносных (58) растений. Местным населением наиболее часто используются 89 видов, относящихся к 72 родам и 35 семействам. Приведены данные об этих видах, с указанием их полезных свойств. Показаны основные характеристики электронной базы данных, ее структура, принцип работы, информация по 24 параметрам растения, вводимая в базу данных и интерфейс выходной информации о растениях.

Ключевые слова: лекарственные, пищевые, кормовые, красильные растения, информационные технологии 